\title{
DETERMINAN OBESITAS PADA ANAK USIA SEKOLAH DASAR
}

\author{
Anita Rahmiwati $^{1 *}$, Rico Januar Sitorus ${ }^{2}$, Ditia Fitri Arinda ${ }^{3}$, Feranita Utama ${ }^{4}$ \\ ${ }^{1,2,3,4}$ Fakultas Kesehatan Masyarakat Universitas Sriwijaya \\ Bagian Gizi dan Epidemiologi Fakultas Kesehatan Masyarakat Universitas \\ Sriwijaya. Jl. Palembang Prabumulih KM. 32, Kabupaten Ogan Ilir, \\ Sumatera Selatan \\ Email:1anitafkmunsri@gmail.com, ${ }^{2}$ marcio_januar@yahoo.co.id, \\ ${ }^{3}$ rd.dityaorin@gmail.com, ${ }^{4}$ fera_ph06@yahoo.co.id
}

\begin{abstract}
Abstrak
Memasuki era globalisasi, Indonesia masih menghadapi masalah gizi ganda, yaitu masalah gizi kurang dan lebih dengan resiko penyakit yang ditimbulkan. Masalah gizi ganda pada hakekatnya merupakan masalah perilaku. Untuk mengkoreksi masalah gizi ganda dapat dilakukan dengan pendekatan melalui pemberian informasi tentang perilaku gizi yang baik dan benar. Pendidikan gizi pada anak usia sekolah dapat meningkatkan pengetahuan gizi anak dan berperan dalam pemilihan makanan dan kebiasaan makan. Pendidikan gizi dan kesehatan mulai diarahkan pada murid TK dan SD mengingat kelompok usia ini memiliki kebiasaan sikap yang masih relatif mudah dibentuk. Desain penelitian yang digunakan adalah cross sectional study, menggunakan total sampling dengan jumlah sampel sebanyak 28 reponden. Lokasi penelitian dilakukan di SD IT Rabbani Indralaya, responden diberikan penyuluhan mengenai gizi anak obesitas yang dilakukan selama 3 kali dengan jeda waktu 1 bulan oleh tim peneliti. Hasil penelitian menunjukkan responden yang tidak obesitas di SD IT Robbani Indralaya sebesar 85,7\%, responden dengan aktivitas fisik rendah sebesar 64,3\%, konsumsi makanan pokok $\leq 3$ kali sehari sebesar $75,0 \%$, sering sarapan dan jajan sebesar $57,1 \%$ dan $67,9 \%$, serta jarang konsumsi snack dan fast food sebesar $64,3 \%$ dan $78,6 \%$. Tidak ada hubungan antara aktivitas fisik, konsumsi makanan pokok, sarapan, konsumsi snack, konsumsi fast food dan jajan dengan status gizi anak di SD IT Robbani Indralaya $(\mathrm{p}>0,005)$.
\end{abstract}

Kata kunci: Gizi, obesitas, sekolah dasar

\begin{abstract}
Entering the era of globalization, Indonesia still faces multiple nutritional problems, namely the problem of malnutrition and over nutrition problems with the risk of disease caused. The problem of double nutrition is essentially a behavioral problem. To correct the double nutrition problem can be done through an approach through providing information about good and correct nutrition behavior. Nutritional education in school-age children can increase knowledge of children's nutrition and play a role in the selection of food and
\end{abstract}


eating habits. Nutrition and health education began to be directed at kindergarten and elementary school students considering this age group has a habit of attitude that is still relatively easy to form. The research design used cross sectional designs, with a total sample of 28 respondents. The location of the study was conducted at Rabbani Indralaya IT Elementary School, respondents was given counseling about the nutrition of obese children which was carried out for 3 times with a lag of 1 month.The results showed that respondents who were not obese at Robbani Indralaya Elementary School were $85.7 \%$, respondents with low physical activity were $64.3 \%$, consumption of staple foods $<3$ times a day was $75.0 \%$, frequent breakfast and snacks were $57.1 \%$ and $67.9 \%$, and rarely snack and fast food consumption by $64.3 \%$ and $78.6 \%$. There was no association between physical activity, consumption of staple foods, breakfast, snack consumption, consumption of fast food and snacks with nutritional status of children at Robbani Indralaya Elementary School $(\mathrm{p}>0,05)$.

Keywords: Nutrition, obesity, elementary student

\section{PENDAHULUAN}

Obesitas merupakan salah satu penyakit yang ada di negara maju, tetapi sekarang obesitas terus bertambah di negara berkembang, terutama di daerah perkotaan. Anak yang menderita kelebihan berat badan di negara berkembang jumlahnya sudah melebihi angka 30 juta anak dan anak yang menderita kelebihan berat pada negara maju sebesar 10 juta anak. Secara global terjadi peningkatan prevalensi obesitas pada anak yang mulanya sebesar $4,2 \%$ pada tahun 1990 dan meningkat menjadi 6,7\% pada tahun 2010 yang diprediksi pada tahun 2020 akan mencapai angka $9,1 \%$ atau sebesar 60 juta. Berdasarkan data hasil Riset Kesehatan Dasar pada tahun 2013, prevalensi gemuk secara nasional di Indonesia adalah $11,9 \%$, yang menunjukkan terjadi penurunan dari 14,0\% pada tahun 2010 (Riskesdas, 2013).

Secara nasional masalah gemuk pada anak usia sekolah (5-12 tahun) masih tinggi yaitu $18,8 \%$, terdiri dari gemuk $10,8 \%$ dan sangat gemuk (obesitas) 8,8 $\%$. Prevalensi gemuk terendah di Nusa
Tenggara Timur $(8,7 \%)$ dan tertinggi di Papua (13,2\%). Sebanyak 13 provinsi dengan prevalensi sangat gemuk diatas nasional, yaitu Aceh, Kalimantan Tengah, Jawa Timur, Banten, Kalimantan Timur, JawaBarat, Sumatera Utara, Kepulauan Riau, Sumatera Selatan, Jambi, Papua, Bengkulu, dan Bangka Belitung (Riskesdas, 2018).

Sasaran strategis untuk memperbaiki gizi masyarakat adalah anak sekolah dasar. Hal ini dikarenakan fungsi organ otak pada masa kanak-kanak mulai terbentuk mantap sehingga dapat dengan cepat mengalami perkembangan. Anak sekolah dasar (SD) merupakan anak yang berusia 6-12 tahun. Supaya tidak terjadinya penyimpangan pada masa tumbuh kembang anak khusunya anak usia sekolah, maka sangat dibutuhkan gizi yang cukup (Depkes RI, 2001). Gizi yang kurang pada anak juga dapat membuat sistem imunnya menjadi lemah. Aktifitas yang cukup berat serta pola makan yang kurang teratur dapat mengakibatkan tidak seimbangnya antara asupan dan kecukupan gizi pada anak. Tidak seimbangnya antara asupan dan 
kecukupan gizi pada anak tersebut dapat menyebabkan masalah gizi ganda seperti gizi lebih dan gizi kurang (Seprianty dkk., 2007)

Dalam rangka membina serta meningkatkan kesiapan siswa dalam praktek kesehatan dibutuhkan intervensi atau upaya perbaikan terhadap faktor sikap dan perilaku. Secara garis besar, intervensi tentang faktor sikap dan perilaku dapat dilakukan dengan dua upaya yang saling bertentangan antara satu dan lainnya, yang mana masing masing memiliki kekurangan serta kelebihan. Kedua upaya tersebut adalah melalui penguatan (enforcement) dan pendidikan (education) / promosi kesehatan (Notoatmodjo, 2007).

Kurangnya pengetahuan tentang gizi menjadi salah satu faktor yang dapat mempengaruhi gizi seseorang. Pengetahuan yang kurang akan membuat berkurangnya kemampuan seseorang dalam mengaplikasikan informasi gizi di kehidupan sehari-hari. Salah satu cara dalam meningkatkan pengetahuan seseorang adalah dengan memberikan pendidikan tentang gizi secara dini. Pendidikan gizi tersebut dapat diberikan dengan cara melakukan penyuluhan, dan membagikan poster, leaflet atau booklet pada anak sekolah (Nuryanto, 2014).

Faktor-faktor yang dapat memperburuk keadaan gizi pada anak usia sekolah adalah perilaku dalam memilih serta menentukan jenis makanan yang mereka sukai. Anak - anak sering kali salah dalam memilih makanan, terutama apabila tidak adanya pengawasan serta petunjuk yang benar dari orang tua dalam memilih makanan yang sehat. Pada anak usia sekolah, kebanyakan dari mereka sangat gemar untuk jajan diluar karena sudah menjadi kebiasaan yang dibawanya dari rumah atau bisa juga kerena pengaruh dari teman. Karna sudah terbiasa membeli jajanan, maka hal ini dapat membuat anak merasa enggan untuk memakan makanan yang sudah disediakan lengkap kandungan nilai gizinya oleh orangtua mereka dirumah. Sebaliknya, anak - anak cenderung lebih menyukai jenis makanan jajanan yang biasa mereka beli seperti macam-macam es, snack kemasan, atau makanan dan minuman lain yang nilai gizinya sangat kurang. Berdasarkan segi praktis, uang saku untuk anak sekolah bisa dikatakan memberi keuntungan karena orang tua tidak perlu sibuk dalam mempersiapkan makanan selingan anak (Notoatmodjo, 2008).

Faktor orangtua merupakan salah satu faktor yang sangat berperan penting dalam konsumsi sayur dan buah pada anak usia prasekolah, karena anak-anak pada usia tersebut lebih sering berada di rumah sehingga ketika makan pun tergantung dengan apa yang disediakan di rumah. Pada tahap usia prasekolah, anak harus mengikuti pola makan orang dewasa karena pada usia prasekolah seorang anak termasuk dalam golongan konsumen yang pasif yaitu belum dapat mengambil dan menentukan makanannya sendiri. Selain kemampuan dalam menerima berbagai jenis makanan yang masih sangat terbatas, mereka juga masih sulit diberikan pengertian tentang makanan (Putra, 2012).

Tentunya makanan untuk anak sekolah harus mempertimbangkan berbagai aspek, seperti aspek ekonomi, sosial dan budaya, agama, tingkat kebutuhan, serta tahap perkembangan anak. Energi total yang dibutuhkan pada anak dengan usia 7-9 tahun sadalah ekitar 1.800 kkal sedangkan anak dengan usia 10-12 tahun membutuhkan setidaknya 2.050 kkal (Sartika, 2012).

\section{METODE PENELITIAN}

Desain penelitian yang digunakan adalah cross sectional study. Lokasi penelitian dilakukan di SD IT Rabbani Indralaya Kabupaten Ogan Ilir Sumatera Selatan. Penelitian ini menggambarkan 
hubungan antara aktivitas fisik dengan status gizi responden serta mengukur aspek pengetahuan dan sikap anak mengenai makanan sehat dan bergizi.

Instrumen dalam penelinian ini adalah kuesioner variabel pengetahuan berisi 15 pertanyaan dimana responden harus memilih jawaban pilihan ganda sedangkan kuesioner sikap berisi 20 pernyataan dimana responden harus menjawab apakah pernyataan tersebut disetujui atau tidak. Jumlah sampel sebanyak 28 responden. Data yang telah dikumpulkan dan didapat melalui hasil pengolahan komputerisasi, kemudian dianalisis dan disajikan dalam bentuk tabel. Selanjutnya hasil akhir dari datadata tersebut diinterpretasikan (dinarasikan).

\section{HASIL DAN PEMBAHASAN}

\section{Karakteristik Responden}

Penelitian ini dilaksanakan di SD IT Robbani Indralaya. Jumlah sampel dalam penelitian ini sebanyak 28 reponden yang disajikan pada Tabel 1 berikut:

Tabel 1. Karakteristik Responden

Berdasarkan Jenis Kelamin, Umur, Kelas, dan Jumlah Uang Jajan

\begin{tabular}{|c|c|c|}
\hline Karakteristik & $\begin{array}{l}\text { Frekuensi } \\
\text { (n) }\end{array}$ & $\begin{array}{c}\text { Persentase } \\
(\%)\end{array}$ \\
\hline \multicolumn{3}{|l|}{ Jenis Kelamin } \\
\hline Laki-laki & 12 & 48,9 \\
\hline - Perempuan & 26 & 57,1 \\
\hline \multicolumn{3}{|l|}{ Umur } \\
\hline - 7 Tahun & 2 & 7,1 \\
\hline - 8 Tahun & 17 & 60,8 \\
\hline - 9 Tahun & 7 & 25,0 \\
\hline - 10 Tahun & 2 & 7,1 \\
\hline \multicolumn{3}{|l|}{ Kelas } \\
\hline - Kelas 3 & 19 & 67,9 \\
\hline - Kelas 4 & 9 & 32,1 \\
\hline \multicolumn{3}{|c|}{ Jumlah Uang Jajan } \\
\hline - $\geq$ Rp. $5000,-$ & 22 & 78,6 \\
\hline$-<$ Rp. 5000,- & 6 & 21,4 \\
\hline $\mathbf{N}$ & 28 & 100 \\
\hline
\end{tabular}

Berdasarkan Tabel 1 diketahui bahwa jenis kelamin responden di SD IT Robbani Indralaya didominasi oleh responden yang berjenis kelamin perempuan sebesar 57,1\%. Berdasarkan kategori umurnya, mayoritas responden berumur 8 tahun sebesar $60,8 \%$. Dan berada di kelas 3 sebesar 67,9. Sedangkan untuk uang jajan, kebanyakan responden memiliki jumlah uang jajan $\geq$ Rp. 5000,yaitu, sebesar 78,6\%.

\section{Analisis Univariat}

Analisis univariat adalah teknik analisis data terhadap variabel, yang mana tiap variabel dianalisis secara mandiri tanpa dikaitkan dengan variabel lainnya. Analisis univariat pada penelitian ini terdiri dari status gizi, tingkat aktivitas fisik, sikap sebelum dan sesudah intervensi, serta pengetahuan sebelum dan sesudah intervensi seperti yang disajikan pada Tabel 2 berikut:

Tabel 2. Distribusi Frekuensi Status Gizi dan Aktivitas Fisik Responden di SD IT

Robbani Indralaya

\begin{tabular}{lcc}
\hline Variabel & $\begin{array}{c}\text { Frekuensi } \\
(\mathbf{n})\end{array}$ & $\begin{array}{c}\text { Persentase } \\
(\mathbf{\%})\end{array}$ \\
\hline Status Gizi & & \\
- Obesitas & 1 & 3,6 \\
- Overweight & 3 & 10,7 \\
- Tidak Obesitas & 24 & 85,7 \\
Aktivitas Fisik & & \\
- Rendah & 18 & 64,3 \\
- Tinggi & 10 & 35,7 \\
\hline \multicolumn{1}{c}{ N } & $\mathbf{2 8}$ & $\mathbf{1 0 0}$ \\
\hline
\end{tabular}

Berdasarkan Tabel 2 diketahui bahwa mayoritas responden di SD IT Robbani Indralaya tidak obesitas sebesar $85,7 \%$. Begitupun dengan aktivitas fisiknya, mayoritas responden dengan aktivitas rendah sebesar $64,3 \%$. 
Tabel 3. Distribusi Frekuensi Pola Makan Responden di SD IT Robbani Indralaya

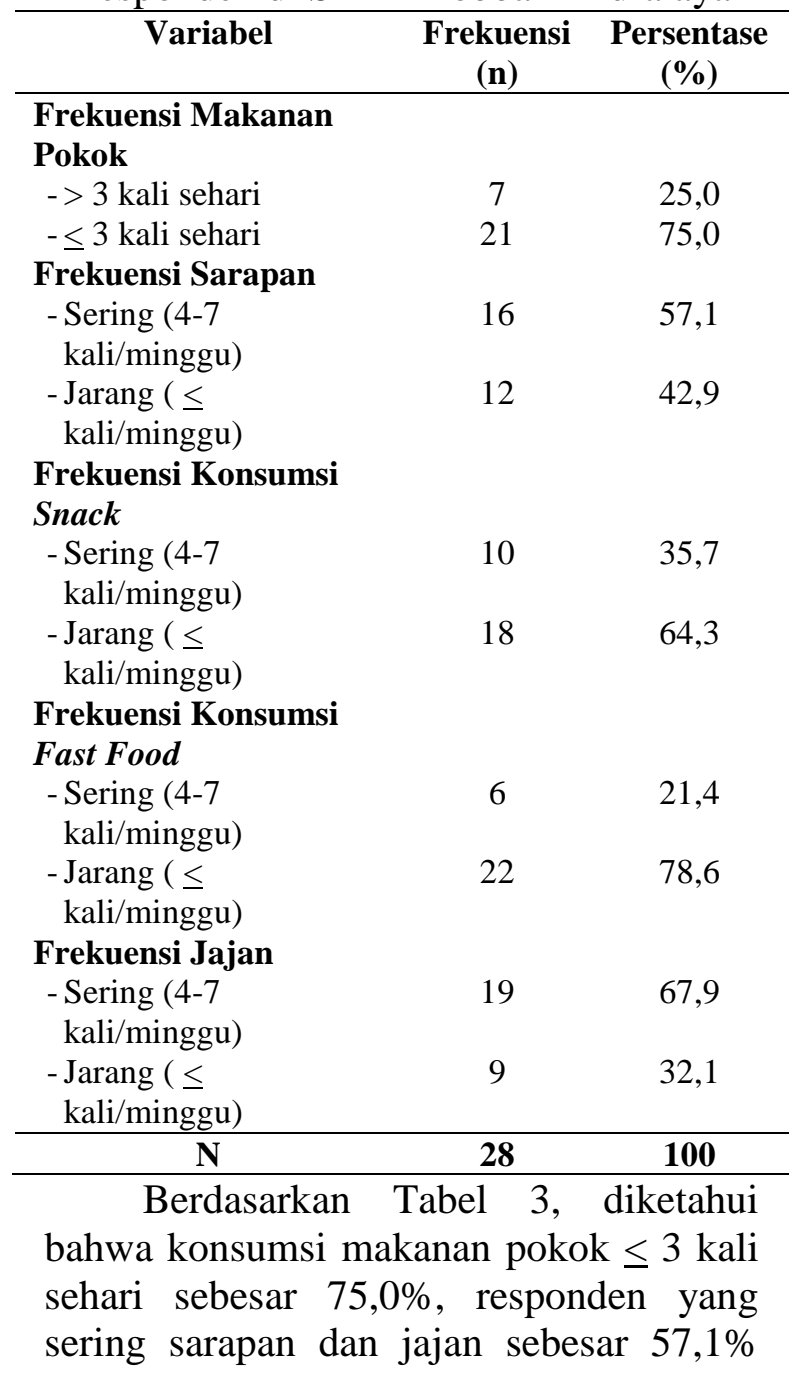

dan 67,9\%. Sedangkan untuk snack dan fast food jarang dikonsumsi oleh responden, yaitu sebesar $64,3 \%$ dan $78,6 \%$.

Tabel 4. Distribusi Frekuensi Sikap dan Pengetahuan Responden di SD IT Robbani Indralaya

\begin{tabular}{cccc}
\hline \multicolumn{2}{c}{ Variabel } & $\begin{array}{c}\text { Frekuensi } \\
(\mathbf{n})\end{array}$ & $\begin{array}{c}\text { Persentase } \\
(\boldsymbol{\%})\end{array}$ \\
\hline Sikap & & & \\
- & Negatif & 12 & 42,9 \\
- & Positif & 16 & 57,1 \\
Pengetahuan & & \\
- & Rendah & 13 & 46,4 \\
- & Tinggi & 15 & 53,6 \\
\hline & N & $\mathbf{2 8}$ & $\mathbf{1 0 0}$ \\
\hline
\end{tabular}

Berdasarkan Tabel 4, diketahui bahwa responden dengan sikap positif sebesar $57,1 \%$. Sedangkan untuk variabel pengetahuan, mayoritas responden memiliki pengetahuan tinggi yaitu sebesar $53,6 \%$.

\section{Analisis Bivariat}

Analisis bivariat dilakukan untuk menganalisis hubungan atau perbedaan antara dua variabel. Untuk menguji hubungan antara aktivitas fisik, konsumsi makanan pokok, sarapan, konsumsi snack, konsumsi fast food, dan jajan dengan status gizi responden digunakan analisis kolmogorov smirnov.

Tabel 5. Hubungan Aktivitas Fisik dan Pola Makan dengan Status Gizi Responden di SD IT Robbani Indralaya

\begin{tabular}{|c|c|c|c|c|c|c|c|c|}
\hline \multirow{3}{*}{\multicolumn{2}{|c|}{ Variabel }} & \multicolumn{6}{|c|}{ Status Gizi } & \multirow{3}{*}{$p$-value } \\
\hline & & \multicolumn{2}{|c|}{ Obesitas } & \multicolumn{2}{|c|}{ Overweight } & \multicolumn{2}{|c|}{ Tidak Obesitas } & \\
\hline & & $\mathbf{N}$ & $\%$ & $\mathbf{n}$ & $\%$ & $\mathbf{n}$ & $\%$ & \\
\hline \multicolumn{9}{|c|}{ Aktivitas Fisik } \\
\hline - & Rendah & 1 & 3,6 & 3 & 10,7 & 14 & 50,0 & 0,909 \\
\hline & Tinggi & 0 & 0,0 & 0 & 0,0 & 10 & 35,7 & \\
\hline \multicolumn{9}{|c|}{ Konsumsi Makanan Pokok } \\
\hline- & $>3$ kali sehari & 1 & 3,6 & 0 & 0,0 & 6 & 21,4 & 1,000 \\
\hline- & $\leq 3$ kali sehari & 0 & 0,0 & 3 & 10,7 & 18 & 64,3 & \\
\hline \multicolumn{9}{|c|}{ Sarapan } \\
\hline- & Sering (4-7 kali/minggu) & 0 & 0,0 & 3 & 10,7 & 13 & 46,4 & 1,000 \\
\hline- & Jarang ( $\leq \mathrm{kali} / \mathrm{minggu})$ & 1 & 3,6 & 0 & 0,0 & 11 & 39,3 & \\
\hline \multicolumn{9}{|c|}{ Konsumsi Snack } \\
\hline- & Sering (4-7 kali/minggu) & 0 & 0,0 & 1 & 3,6 & 9 & 32,1 & 1,000 \\
\hline- & Jarang ( $\leq \mathrm{kali} /$ minggu $)$ & 1 & 3,6 & 2 & 7,1 & 15 & 53,6 & \\
\hline \multicolumn{9}{|c|}{ Konsumsi Fast Food } \\
\hline- & Sering (4-7 kali/minggu) & 1 & 3,6 & 0 & 0,0 & 5 & 17,9 & 0,999 \\
\hline- & Jarang ( $\leq$ kali/minggu $)$ & 0 & 0,0 & 3 & 10,7 & 19 & 67,8 & \\
\hline \multicolumn{9}{|l|}{ Jajan } \\
\hline - & Sering (4-7 kali/minggu) & 1 & 3,6 & 3 & 10,7 & 15 & 53,6 & 0,949 \\
\hline- & Jarang ( $\leq$ kali/minggu) & 0 & 0,0 & 0 & 0,0 & 9 & 32,1 & \\
\hline
\end{tabular}


Berdasarkan Tabel 5, diketahui responden dengan aktivitas fisik rendah (50\%), konsumsi makanan pokok $\leq 3 \mathrm{kali}$ sehari $(64,3 \%)$, sering sarapan $(46,4 \%)$ dan jajan $(53,6 \%)$, serta jarang konsumsi snack $(53,6 \%)$ dan fast food $(67,8 \%)$ tidak mengalami obesitas. Berdasarkan hasil analisis kolmogorov smirnov didapatkan nilai $p$-value $>0,05$ pada masing-masing variabel yang artinya tidak ada hubungan antara aktivitas fisik, konsumsi makanan pokok, sarapan, konsumsi snack, konsumsi fast food, dan jajan dengan status gizi anak di SD IT Robbani Indralaya.

\section{Hubungan Aktivitas Fisik dengan Status Gizi Responden di SD IT RobbaniIndralaya}

Hasil analisis univariat menunjukkan bahwa sebagian besar responden memiliki aktivitas fisik yang rendah. Berdasarkan hasil analisis kolmogorov smirnov diketahui bahwa tidak ada hubungan antara aktivitas fisik dengan status gizi anak di SD IT Robbani Indralaya. Hal ini sejalan dengan penelitian Wardiani (2011) yang menjelaskan bahwa tidak terdapat hubungan antara aktivitas fisik dengan status gizi siswa. Dalam suatu penelitian menjelaskan bahwa siswa yang memiliki aktivitas fisik $<30$ menit berisiko hampir 3 kali lebih besar untuk mengalami kelebihan berat badan (Putri, 2017)

Tidak adanya hubungan atara aktivitas fisik dengan status gizi anak di SD IT Robbani Indralaya dikarenakan sebagian besar responden dengan aktivitas fisik yang rendah juga memiliki status gizi normal (tidak obesitas). Aktivitas fisik yang dilakukan siswa-siswi di SD IT Robbani Indralaya tergolong dalam aktivitas fisik ringan dan sedang, karena sebagian besar aktivitas fisik yang dilakukan yaitu berada didalam kelas dengan melakukan kegiatan seperti duduk, menulis, dan membaca. Selain itu kegiatan olahraga yang dilakukan disekolah tersebut tidak sering dilakukan dalam satu minggu. Kurangnya aktivitas fisik menjadi salah satu faktor penyebab terjadinya kegemukan dan obesitas pada anak sekolah. Keterbatasan lapangan untuk bermain dan kurangnya fasilitas untuk beraktivitas fisik menyebabkan anak memilih untuk bermain di dalam rumah. Selain itu, kemajuan teknologi berupa alat elektronik seperti video games, playstation, televisi dan komputer menyebabkan anak malas untuk melakukan aktivitas fisik. Pencegahan dilakukan melalui pendekatan kepada anak sekolah beserta orang-orang terdekatnya (orang tua, guru, teman, dll) untuk mempromosikan gaya hidup sehat meliputi pola dan perilaku makan serta aktivitas fisik. Strategi pendekatan dilakukan pada semua anak sekolah baik yang berisiko menjadi kegemukan dan obesitas maupuntidak (Kemenkes RI, 2012).

Aktivitas fisik atau olahraga yang rutin dapat mendorong penurunan yang cukup besar pada jaringan lemak, bahkan tanpa adanya penurunan berat badan. Intensitas aktivitas fisik pada setiap orang bervariasi, tergantung pada tingkat kebugaran jasmani tiap individu (WHO, 2016). Intentitas dari aktivitas fisik adalah energi yang dikeluarkan terkait dengan aktivitas yang dilakukan. Banyaknya energi yang dibutuhkan bergantung pada beberapa banyak otot yang bergerak, berapa lama dan berapa berat pekerjaan yang dilakukan (Almatsier, 2003).

\section{Hubungan Pola Makan dengan Status Gizi Responden di SD IT Robbani Indralaya}

Penerapan pola makan seimbang dan peningkatan aktivitas fisik pada anak sekolah bukanlah hal yang mudah. Diperlukan dukungan dari orang tua, guru, 
tenaga kesehatan, dan pihak lainnya. Berkaitan dengan hal itu maka upaya penanggulangan ini harus menjadi komitmen nasional yang harus dilakukan secara sistimatis dan terpadu serta berkelanjutan. Usaha pencegahan dimulai dari lingkungan keluarga, sekolah, masyarakat dan fasilitas pelayanan kesehatan. Lingkungan sekolah merupakan tempat yang baik untuk pendidikan kesehatan yang dapat memberikan pengetahuan, keterampilan serta dukungan sosial dari warga sekolah. Pengetahuan, keterampilan serta dukungan sosial ini memberikan perubahan perilaku makan sehat yang dapat diterapkan dalam jangka waktu lama. Tujuan pencegahan ini adalah terjadinya perubahan pola dan perilaku makan meliputi meningkatkan kebiasaan konsumsi buah dan sayur, mengurangi konsumsi makanan dan minuman manis, mengurangi konsumsi makanan tinggi energi dan lemak, mengurangi konsumsi junk food, serta peningkatan aktivitas fisik dan mengurangi sedentary life style (Kemenkes RI, 2012).

Berdasarkan hasil analisis kolmogorov smirnov didapatkan nilai $p>0,005$ pada masing-masing variabel, yang artinya tidak ada hubungan antara konsumsi makanan pokok, sarapan, konsumsi snack, konsumsi fast food, dan kebiasaan jajan dengan status gizi anak di SD IT Robbani Indralaya. Tidak adanya hubungan konsumsi makan pokok dengan status gizi dikarenakan kebanyakan responden yang mengkonsumsi makanan pokok>3 kali sehari tidak mengalami obesitas. Begitupun dengan responden yang sering sarapan, mayoritas dari responden tersebut tidak mengalami obesitas. Selain itu, sarapan hanya menyumbang sedikit asupan dari kebutuhan sehari-hari sehingga tidak bisa dijadikan faktor utama dalam mempengaruhi status gizi seseorang. Sama halnya untuk konsumsi snack dan juga fast food, responden yang sering mengkonsumsi snack, fast food, dan jajan disekolah kebanyakan tidak mengalami obesitas, semua pasti sudah tau bahwa fast food merupakan salah satu faktor yang menyebabkan kegemukan akan tetapi hal ini juga tergantung pada jumlah porsi yang dikonsumsi oleh sesorang, apabila porsi yang dimakan sedikit maka hal ini tidak akan berpengaruh siginifikan terhadap status gizi. Sedangkan untuk kebiasaan jajan, rata-rata responden membeli jajanan yang tidak terlalu berpotensi menyebabkan kegemukan dan dalam porsi yang kecil seperti susu, wafer, dan roti.

SD IT Robbani Indralaya menyediakankan kantin dalam sekolah dan tidak ada jajanan dari luar sekolah sehingga kualitas dari jajanan para siswa sudah dipastikan aman. Kantin sekolah yang ada di SD IT Robbani menjual makanan dan minuman kemasan, selain itu kantin sekolah juga menjual makanan yang sudah diolah. Salah satu contoh makanan olahan tersebut ialah tekwan, bubur ayam, es teh, dan aneka gorengan. Selain mengkonsumsi jajanan sekolah, para siswa juga membawa makanan dari rumah. Jajanan anak sekolah merupakan masalah yang perlu diperhatikan masyarakat, khususnya orang tua dan guru karena makanan jajanan ini sangat berisiko terhadap cemaran biologis atau kimiawi yang banyak mengganggu kesehatan, baik jangka pendek maupun jangka panjang. Ibu mempunyai peran penting dalam mengatur dan mengendalikan arus makanan dalam keluarga, sehingga pengetahuan ibu khususnya tentang gizi sangat menentukan terhadap pola konsumsi makan dalam keluarga, khususnya kebiasaan makan anak. Walaupun pengetahuan gizi ibu akan meningkat dengan pemberian pendidikan gizi, namun tingkat sosial ekonomi terutama pendapatan keluarga yang rendah akan menjadi tantangan 
tersendiri bagi ibu terutama dalam memilih bahan makanan yang akan disajikan dengan keuangan yang terbatas (Zulaekah, 2012). Tingkat sosial ekonomi yang membaik dalam keluarga akan semakin mempermudah ibu untuk mendapatkan berbagai macam bahan makanan yang sesuai dengan pilihan dan selera (Hadi dkk., 2005).

Pola makan yang merupakan pencetus terjadinya kegemukan dan obesitas adalah mengkonsumsi makanan porsi besar (melebihi dari kebutuhan), makanan tinggi energi, tinggi lemak, tinggi karbohidrat sederhana dan rendah serat. Sedangkan perilaku makan yang salah adalah tindakan memilih makanan berupa junk food, makanan dalam kemasan dan minuman ringan (soft drink) (Kemenkes RI, 2012). Faktor-faktor yang dapat memperburuk keadaan gizi pada anak usia sekolah adalah perilaku dalam memilih serta menentukan jenis makanan yang mereka sukai. Anak- anak sering kali salah dalam memilih makanan, terutama apabila tidak adanya pengawasan serta petunjuk yang benar dari orang tua dalam memilih makanan yang sehat. Pada anak usia sekolah, kebanyakan dari mereka sangat gemar untuk jajan diluar karena sudah menjadi kebiasaan yang dibawanya dari rumah atau bisa juga kerena pengaruh dari teman. Karna sudah terbiasa membeli jajanan, maka hal ini dapat membuat anak merasa enggan untuk memakan makanan yang sudah disediakan lengkap kandungan nilai gizinya oleh orangtua mereka dirumah. Sebaliknya, anak - anak cenderung lebih menyukai jenis makanan jajanan yang biasa mereka beli seperti macam-macam es, snack kemasan, atau makanan dan minuman lain yang nilai gizinya sangat kurang. Berdasarkan segi praktis, uang saku untuk anak sekolah bisa dikatakan memberi keuntungan karena orang tua tidak perlu sibuk dalam mempersiapkan makanan selingan anak (Notoatmodjo, 2008)
Pengetahuan gizi pada anak usia sekolah merupakan salah satu faktor yang menentukan pola konsumsi pangan dan status gizi. Pendidikan gizi pada anak usia sekolah dapat meningkatkan pengetahuan gizi anak dan bereperan dalam pemilihan makanan dan kebiasaan makan. Dengan semakin tingginya pengetahuan gizi seseorang maka diharapkan akan semakin baik pula keadaan gizi orang tersebut. Peningkatan pengetahuan gizi bisa dilakukan dengan program pendidikan gizi. Dengan adanya program pendidikan gizi, maka diharapkan dapat memberikan dampak terhadap pengetahuan, sikap, dan perilaku anak sekolah terhadap pola konsumsi makannya. Sikap terhadap gizi yang kurang tepat dapat diubah melalui pendidikan gizi dan upaya-upaya pendidikan gizi pada anak-anak lebih efektif dilakukan di sekolah.

\section{KESIMPULAN}

Hasil penelitian menunjukkan responden yang tidak obesitas di SD IT Robbani Indralaya sebesar $85,7 \%$. Mayoritas responden dengan aktivitas fisik rendah $(64,3 \%)$, konsumsi makanan pokok $\leq 3$ kali sehari $(75,0 \%)$, sering sarapan $(57,1 \%)$ dan jajan $(67,9 \%)$, serta jarang konsumsi snack $(64,3 \%)$ dan fast food $(78,6 \%)$. Tidak ada hubungan antara aktivitas fisik, konsumsi makanan pokok, sarapan, konsumsi snack, konsumsi fast food dan jajan dengan status gizi anak di SD IT Robbani Indralaya $(p>0,05)$.

\section{UCAPAN TERIMA KASIH}

Ucapan terimakasih diberikan kepada Universitas Sriwijaya yang telah memberikan dana penelitian serta pihakpihak yang berjasa dalam membantu pelaksanaan penelitian. 


\section{DAFTAR PUSTAKA}

Almatsier, S. (2003). Prinsip Dasar Ilmu Gizi. PT. Gramedia Pustaka Utama, Jakarta. Bertalina. (2015). Pengaruh Promosi Kesehatan Terhadap Peningkatan Pengetahuan Tentang Gizi Seimbang Pada Siswa Sekolah Dasar Negeri Di Kecamatan Rajabasa Kota Bandar Lampung. Jurnal Kesehatan, 1(1): 56-63.

Depkes RI. (2001). Pedoman Penyuluhan Gizi pada Anak Sekolah Bagi Petugas Penyuluhan. Ditjen Bina Kesehatan Masyarakat Direktorat Gizi Masyarakat. Jakarta.

Depkes RI. (2013). Riset Kesehatan Dasar (Riskesdas). Badan Penelitian dan Pengembangan Kesehatan, Departemen Kesehatan, Republik Indonesia. Jakarta.

Depkes RI. (2018). Riset Kesehatan Dasar (Riskesdas). Badan Penelitian dan Pengembangan Kesehatan, Departemen Kesehatan, Republik Indonesia. Jakarta.

Hadi, S.M., Sulityowati, E., \& Mifbakhuddin. (2005). Hubungan pendapatan perkapita, pengetahuan gizi ibu dan aktivitas fisik dengan obesitas anak kelas 4 dan 5 di SD Hj. Isriati Baiturrahman kota Semarang. Jurnal Kesehatan Masyarakat Indonesia. 2005; 2(1):7-12.

Kemenkes RI. (2012). Pedoman Pencegahan dan Penanggulangan Kegemukan dan Obesitas pada Anak Usia Sekolah. Departemen Kesehatan Republik Indonesia, Jakarta.

Notoatmodjo, S. (2008). Pedoman Promosi Kesehatan di Sekolah. Depkes RI. Jakarta.

Notoatmodjo, S. (2014). Promosi Kesehatan dan Ilmu Perilaku. PT Rineka Cipta, Jakarta.

Nuryanto, Pramono, A., Puruhita, N., \& Muis, S. F. (2014). Pengaruh Pendidikan Gizi Terhadap Pengetahuan dan Sikap Tentang Gizi Anak Sekolah Dasar. Jurnal Gizi Indonesia, 3(1): 32-36 (ISSN : 1858-4942).

Putra, W.K. (2016). Faktor-faktor yang Berhubungan dengan Konsumsi Buah dan Sayur pada Anak Sekolah Dasar. Skripsi. Fakultas Ilmu Keolahragaan Universitas Negeri Semarang. Semarang.

Putri, A. (2017). Hubungan Antara Asupan Makanan, Aktivitas di Waktu Senggang dan Jenis Kelamin dengan Status Gizi Lebih pada Anak-Anak di SD Vianney Jakarta Barat Tahun 2017. Skripsi. Fakultas Kesehatan Masyarakat, Universtitas Indonesia, Depok.

Safitri, N.R.D. \& Fitrianti, D.Y. (2016). Pengaruh Edukasi Gizi dengan Ceramah dan Booklet terhadap Peningkatan Pengetahuan dan Sikap Gizi Remaja Overweight. Jurnal of Nutrition Collage. Program Studi Ilmu Gizi Fakultas Kedokteran Universitas Diponegoro, 5(4): 374-380.

Sartika, R.A. (2012). Penerapan Komunikasi, Informasi, dan Edukasi Gizi terhadap Perilaku Sarapan Siswa Sekolah Dasar. Jurnal Kesehatan Masyarakat Nasional, 7(2).

Seprianty, V., Tjekyan, S. R. M., \& Thaha, M. A. (2015). Status Gizi Anak Kelas III Sekolah Dasar Negeri 1 Sungaililin. Jurnal Kedokteran dan Kesehatan, 2(1): 129-134.

Wardiani, R.D. (2011). Hubungan Antara Aktivitas Fisik dengan Status Gizi Siswa Sekolah Dasar di SD N Kartasura 1, Kecamatan Kartasura, Kabupaten 
Sukoharja. Fakultas Ilmu Kesehatan, Universitas Muhamadiyah Surakarta. Surakarta.

World Health Organization (WHO). (2016). Global Health Observatory (GHO) Data, http://www.who.int/gho/ncd/risk_factors/overweight_text/en/ diakses 20 November 2018.

Zulaekah. (2012). Penyuluhan Gizi dengan Media Komik untuk Meningkatkan Pengetahuan Tentang Keamanan Makanan Jajanan. Jurnal Kesehatan Masyarakat. Fakultas Ilmu Kesehatan, Universitas Muhammadiyah Surakarta, Indonesia, 8(1): 67-73.

Zulaekah, S. (2012). Efektivitas Penddikan Gizi dengan Media Booklet terhadap Penegetahuan Gizi Anak SD. Jurnal Kesehatan Masyarakat. Prodi Gizi, Fakultas Ilmu Kesehatan, Universitas Muhammadiyah Surakarta, Indonesia,7 (2): 121-128. 